\title{
Slaughtering Buffalo in the 'Bantai Adat', Tradition During Eid Before and During the Covid-19 Pandemic in Padang Pariaman Regency West Sumatra Province, Indonesia
}

\author{
Adi Tiya Warman ${ }^{1}$, Bayu Andri Atmoko ${ }^{1}$, Hamdani Maulana ${ }^{1}$, and Endang Baliarti ${ }^{1 *}$ \\ ${ }^{1}$ Department of Animal Production, Faculty of Animal Science, Universitas Gadjah Mada, Jl. Fauna No 3, Kampus \\ UGM, Bulaksumur, Yogyakarta, Indonesia, 55281 \\ *Corresponding author. Email: bali_arti@ugm.ac.id
}

\begin{abstract}
Eid is an Islamic holiday celebrated lively in Indonesia, including in Padang Pariaman, West Sumatera Province, with the tradition of slaughtering buffalo in the village as a form of community togetherness. The occurrence of the COVID19 pandemic disaster impacted the socio-economic conditions of the community and various restrictions such as gatherings. This study aims to examine the "Bantai Adat" tradition during Eid in Batang Anai and Ulakan Tapakis Subdistrict, Padang Pariaman Regency, West Sumatra, while the pandemic is still ongoing. Research involving 35 respondents from family heads as participants and six administrators/committees for the Bantai Adat event, using interviews and direct observation at the location. The results showed the buffalo slaughtered decreased during a pandemic; in Batang Anai and Ulakan Tapakis sub-districts in 2018, were 2.00 \pm 0.00 and 2.25 \pm 1.26 heads, in 2019 were $2.00 \pm 0.00$ and $2.25 \pm 1.26$ heads, in 2020 were $1.00 \pm 1.41$ and $2.25 \pm 1.26$ heads, in 2021 were $1.50 \pm 0.71$ and $2.25 \pm$ 1.26 heads. The price of buffalo slaughtered in Batang Anai and Ulakan Tapakis sub-districts were Rp.27,000,000.00 \pm $1,870,828.69$ and Rp.25,500,000 $\pm 707,106.78$, respectively; the price of meat/pack was Rp.175,000 $\pm 35,355$ and $125,000.00 \pm 5,773.50$; It concluded that despite significant disasters such as the covid-19 pandemic, the tradition of slaughtering buffalo during Eid was maintained even though the number decreased. Therefore, more attention to the development of local buffalo was needed.
\end{abstract}

Keywords: Buffalo, Covid-19 Pandemic, Local tradition, Padang Pariaman Regency, Traditional slaughter

\section{INTRODUCTION}

Indonesian is a pluralistic nation, seen from the ethnic groups scattered in the Indonesian archipelago, inhabiting around 16,056 islands [1], and had a different culture and its uniqueness. Some cultural traditions and religious ceremonies involve livestock, for example in religious activities. at the time of Eid al-Adha; livestock are used as sacrificial animals such as cows, buffaloes, goats, and sheep [2]. [3], there are 2 cultural activities involving cows carried out by the community in Madura, namely Sonok and Karapan. Sonok is a cattle contest activity, while Karapan is a cow racing activity that is carried out after the harvest season. In addition, there is also the Meugang Tradition [4], a typical tradition from Aceh which is held three times a year, namely two days before the month of Ramadan, Eid al-Fitr, and Eid alAdha celebrations. A similar tradition is also carried out by the Minangkabau community in West Sumatra, namely the Bantai Adat.
Bantai adat is a tradition that is still preserved by the Minang community, especially in the Padang Pariaman area. Bantai adat is a tradition of slaughtering buffalo for meat and by-products, then cooking it into rendang and other Minang specialties made during Eid al-Fitr. Eid alFitr or "Gayo Gadang" in the traditional Padang Pariaman calendar system after carrying out the Eid prayer, the community performs the traditional slaughtering tradition or Mandabiah Kabau (Slaughtering buffalo). The buffalo is slaughtered by a Labai or chaplain at the mosque, and then the process of dividing the meat is carried out in mutual cooperation. The meat is distributed to the people who have pre-ordered during the preparatory meeting for slaughtering at the mosque. Meat that is distributed to the community is not free, but the community must pay the price of meat in the market [5].

At the end of 2019, the world was shocked by the emergence of a disease that spread massively throughout the world, caused by a viral infection named COVID-19. 
In order to simplify and accelerate the handling of COVID-19, the Government through the Ministry of Health issued the Minister of Health Regulation No. 9 of 2020 concerning Guidelines for Large-Scale Social Restrictions. These restrictions include closing schools and workplaces, restrictions on religious activities, restrictions on places or public facilities, restrictions on social, and cultural activities, restrictions on transportation modes and other activities related to defense, and security aspects. The spread of the coronavirus which has spread to various regions in Indonesia and has an impact on the Indonesian economy, both in terms of trade, investment and tourism.

Communities in West Sumatra, including in Padang Pariaman Regency, have also experienced the impact of the Covid-19 pandemic, which has led to restrictions on religious and cultural events. So that changes and restrictions related to religious and cultural events are also carried out, one of which is the implementation of traditional slaughter. Therefore, a study was conducted on whether the COVID-19 pandemic had an impact on the level of buffalo slaughter in the Bantai Kabau tradition in Padang Pariaman Regency which has been ritually carried out for centuries from generation to generation and research needs to be carried out in relation to the future of buffalo farming in West Sumatra, as one of the provinces with the largest buffalo population in Indonesia, which is $7.25 \%$ in 2020 based on the Central Statistics Agency in 2021.

\section{MATERIAL AND METHODS}

\subsection{Material}

The research was carried out in Ulakan Tapakis and Batang Anai sub-districts, Padang Pariaman district,

Table 1. Characteristics of Bantai Adat administrators
West Sumatra province, from April to May 2021, before and during the Bantai Adat ceremony. The selection of the two sub-districts was based on the number of human populations and the highest buffalo population was in the two sub-districts.

The research object is the committee and participants of the Bantai Adat celebration. Data collection and analysis of the level of buffalo slaughter was carried out by interviewing the committee as many as six people and the traditional slaughter participants as many as 35 people. Observation of the characteristics of the buffalo used and slaughtered was carried out on 12 buffaloes.

\subsection{Methods}

Generals. The data recorded includes the characteristics of the administrator, including the age of the board, experience in managing the traditional slaughtering tradition, education, and work. The data on the characteristics of the administrators were obtained by means of direct interviews with the administrators using a prepared questionnaire. Characteristics of Participants include the age of participants, income, education, occupation, the purpose of participating in traditional slaughter. Characteristics of buffalo include breed, gender, and qualitative characteristics of buffalo, number of cattle, price of livestock, price, and weight of one pile/package. Buffalo characteristic data was obtained by observing the buffalo directly before being slaughtered.

Statistic. The data obtained were analyzed descriptively quantitatively to get the mean \pm standard deviation.

\begin{tabular}{|l|c|c|}
\hline \multirow{2}{*}{ Variable } & \multicolumn{2}{|c|}{ Sub-District } \\
\cline { 2 - 3 } & Batang Anai (N=2) & Ulakan Tapakis (N=4) \\
\hline Administrators Age & $51.00 \pm 12.73$ & $55.25 \pm 18.03$ \\
\hline Management experience & $10.00 \pm 7.07$ & $23.25 \pm 20.02$ \\
\hline Educations (\%) & - & - \\
\hline No school & 100 & 50 \\
\hline Primary school & - & 25 \\
\hline Junior high school & - & 25 \\
\hline Senior high school & - & \\
\hline Bachelor & & 25 \\
\hline Profession (\%) & 100 & \\
\hline Farmer & & \\
\hline Entrepreneur & & \\
\hline
\end{tabular}




\section{RESULT AND DISCUSSION}

\subsection{Characteristics of Bantai Adat administrators and participants.}

The characteristics of the Bantai Adat administrators in Padang Pariaman, West Sumatra are shown in Table 1. The results showed that the Bantai Adat administrators were still of productive age. are in the age range between 15 to 64 years [6], have been able to produce goods, and services and share of the population who take part in ongoing labor activities. Seen from the experience in managing, the Bantai Adat administrators have good experience in managing the Bantai Adat events with quite a long experience. Management experience is directly proportional to the level of public confidence in the ability of the management. [7] states that someone who has had a long working period will get better trust from others in carrying out their duties, work implementation will run smoothly, and authority will increase.

The education level of the Bantai Adat administrators varies from elementary school to university level but is dominated by elementary school graduates, even in Batang Anai sub-district $100 \%$ elementary school graduates, while in Ulakan Tapakis sub-district 50\% elementary school graduates. The main job of the administrators is farmers and entrepreneurs, besides that the administrators are also important people in the village, namely scholars, smarted people at Nagari.

The characteristics of the Bantai Adat participants can be seen in Table 2 .

The results showed that the Bantai Adat participants were still classified as productive age with their monthly income in Batang Anai and Ulakan Tapakis Sub-districts,

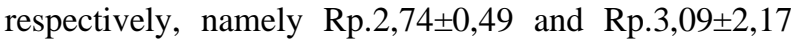
millions. The average number of packages purchased by the community did not differ much, the number of packages purchased by bantai adat participants in Batang Anai and Ulakan Tapakis sub-districts was $2.15 \pm 1.17$ and $2.63 \pm 1.60$ packages, respectively. In terms of income, the participants actually do not belong to the society with more income, but they still take part as participants, showing that this custom is firmly held by the community.

Based on the results of the study obtained motivation to join the tradition in terms of socio-cultural aspects and aspects of the livestock used. The motivation from the socio-cultural aspect is preserving traditions, maintaining the nature of mutual cooperation, and establishing friendships with fellow citizens. Based on the livestock aspect, the meat produced comes from a trusted slaughter, the meat is fresh because it is cut directly and witnessed by the community or Bantai Adat participants, even though it is carried out during a pandemic. After carrying out the Eid prayer, the community carries out the mandabiah kabau tradition (slaughtering buffalo). The buffalo is slaughtered by a Labai or my chaplain at the mosque, then the process of dividing the meat is carried out in mutual cooperation. [5] stated that based on the traditional calendar in the Padang Pariaman area in the month of Gayo (Syawal) after performing the Eid prayers, the community carried out the mandabiah kabau tradition (slaughtering buffalo). The buffalo is slaughtered by a Labai or chaplain at the mosque, then the process of dividing the meat is carried out in mutual cooperation.

Table 2. of Characteristics of Bantai Adat Participants

\begin{tabular}{|l|c|c|}
\multirow{2}{*}{\multicolumn{2}{c|}{ Variable }} & \multicolumn{2}{c|}{ Sub-District } \\
\hline Participants Age & $53.59 \pm 12.04$ & Ulakan Tapakis (N=8) \\
\hline Income (Millions) & $2.74+0.49$ & $54.00 \pm 16.04$ \\
\hline Educations(\%) & & $3.09 \pm 2.17$ \\
\hline No school & 3.70 & - \\
\hline Primary school & 59.26 & 62.5 \\
\hline Junior high school & 11.11 & - \\
\hline Senior high school & 25.93 & 12.5 \\
\hline Bachelor & - & 25 \\
\hline Profession (\%) & & 75 \\
\hline Farmer & 81.48 & 25 \\
\hline Entrepreneur & 11.11 & - \\
\hline Housewife & 7.41 & $2.63 \pm 1.60$ \\
\hline Purchased Packages & $2.15 \pm 1.17$ & \\
\hline
\end{tabular}


Table 3. Quantity and Characteristics of Slaughtered Buffalo

\begin{tabular}{|l|c|c}
\multirow{2}{*}{ Breed } & \multicolumn{2}{|c}{ Sub-District } \\
\cline { 2 - 3 } & Batang Anai (N=3) & Ulakan Tapakis (N=9) \\
\hline Sex & Mud Buffalo & Mud Buffalo \\
\hline Quantity (head) & Male & Male \\
\hline 2018 & 4 & 9 \\
\hline 2019 & 4 & 9 \\
\hline 2020 & 2 & 9 \\
\hline 2021 & 3 & $27.00 \pm 1.87$ \\
\hline Price (Millions Rupiah) & $25.50 \pm 0.71$ & $1.25 \pm 0.06$ \\
\hline Weight(Kg)/package & $1.70 \pm 0.42$ & $125 \pm 5.77$ \\
\hline Price/package (thousand Rupiah) & $175 \pm 35.36$ & \\
\hline Characteristicss & Dark brown in color, back arched horns, short leg, solid and compact \\
& body, the bottom of the neck has 2 white lines \\
\hline
\end{tabular}

\subsection{Characteristics of Buffalo Livestock.}

The breed of buffalo used for the Bantai Adat is the Mud buffalo with male sex and does not have specific criteria. The buffalo used has characteristics in accordance with the characteristics of the mud buffalo according to [8], the color that covers the buffalo's body is gray to black, not different from the characteristics of the buffalo in Sumbawa with the dominant skin color being black and brown $(56,6 \%)$. Local buffaloes have chevron lines or necklines varying between none, single and double. [9] found the shape of a local buffalo horn in Central Lombok which was found to be curved backward slightly downwards and the horns curved upwards. The body shape is short and fat, the legs are rather short and straight and the chest circumference is rather wide.

The rate of slaughter of buffalo (Table 3) for the last four years in Batang Anai Sub-district is not significantly different, butchering in 2020 is reduced by one buffalo because there is one village that does not carry out the Bantai Adat tradition with consideration of social restrictions. In the District of Ulakan Tapakis the number did not differ, namely nine buffalos. The slaughter of each village in the Ulakan Tapakis sub-district was obtained on average annually from 2018 to 2021 as much as $2.25 \pm 1.26$ heads. Meanwhile, in Batang Anai subdistrict in 2018 and 2019, there were $2.00 \pm 0.00$ head, and in 2020 and 2021 it fell to $1.00 \pm 1.41$ head and 1.50 \pm 0.71 head.

The buffalo used is an adult male buffalo with the average price in Batang Anai and Ulakan Tapakis sub-

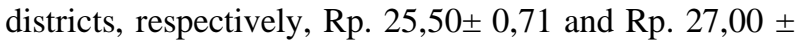
1,87 millions. The system for purchasing meat carried out during the Bantai Adat is a package system or in Minang language called 'Onggok' with different prices from one area to another; the price of one package in Batang Anai and Ulakan Tapakis sub-districts, respectively, is $\mathrm{Rp}$. $175 \pm 35,36 \mathrm{~kg}$ and Rp. $125 \pm 5,77$ thousand, with an average weight of $1,70 \pm 0,42 \mathrm{~kg}$ and $1.25 \pm 0.06 \mathrm{~kg}$. The price of Bantai Adat meat packages has a positive correlation with the number of packages purchased, the cheaper the package price, the more meat packages purchased, the average number of packages purchased in Batang Anai and Ulakan Tapakis sub-districts respectively is $2.15 \pm 1.17$ packages and $2.63 \pm 1.60$ packages.

The slaughtering are usually carried out in one place but during the 2020 and 2021 pandemic, they will be carried out in each mosque in every village, due to largescale social restrictions that prohibit people from gathering to prevent the transmission of Covid-19. The implementation of the Traditional Bantai in 2020 and 2021 refers to the Ministry of Health regulation number 9 of 2020 regarding the guidelines for large-scale social restrictions in point $\mathrm{D}$ no 5 , namely restrictions on social and cultural activities carried out in the form of prohibiting crowds of people in social and cultural activities and guided by the views of traditional institutions. officially recognized by the government and the laws and regulations.

\section{CONCLUSION}

The amount of buffalo slaughtered at the Bantai Adat before and during the Covid-19 outbreak did not decrease in large numbers, indicating that this traditional event is held very strongly by the Minang community, so attention is needed for its existence and development programs in the future. 


\section{REFERENCES}

[1] Badan Pusat Statistik Indonesia (BPS-Statistic Indonesia). 2021. Statistik Indonesia 2021 (Statistical Yearbook of Indonesia 2021).

[2] Ibrahim, A., W. T. Artama., R. Widayanti., M. D. E. Yulianto., D. Faqar., I. G. S. Budisatria. 2019. Sheep traders preferences on marketing place and their satisfaction during Eid al-Adha period in Yogyakarta, Indonesia. The 1st Animal Science and Food Tehnology Conference (AnSTC)2019.1-5.

[3] Widi, T. S. M., H. M. J. Udo., K. Oldenbroek., I. G. S. Budisatria., E. Baliarti., and A. J. Van der Zijpp. 2014. Unique cultural values of Madura cattle: is cross-breeding a threat?. Animal Genetic Resources. Vol 54:141-152.

[4] Budisatria, I. G. S., A. Ibrahim., H. Koesmara., E. Baliarti., T. S. M. Widi., and B. A. Atmoko. 2019. Income analysis and market profile of live cattle and meat traders during Megangi festivity and normal market situation in North Aceh Regency. The 1st Animal Science and Food Technology Conference (AnSTC)2019. pp. 1-5.

[5]. Yunis, M. 2021. Sistem Kalender Tradisional di Padang Pariaman (Traditional Calendar System in Padang Pariaman). Diakses pada 8 Juli 2021 Pukul (Accessed July 8, 2021 At 09.00 a.m). httprepo.unand.ac.idideprint10313.pdf

[6] Sukmaningrum, A., A. Imron. 2017. Memanfaatkan usia produktif dengan usaha kreatif industri pembuatan kaos pada remaja di Gresik (Utilizing productive age with creative efforts in the t-shirtmaking industry for teenagers in Gresik). Paradigma. 5(3):1-6.

[7] Putri, M. A. D. 2017. Pengaruh pengalaman kerja, penilaian prestasi kerja dan hubungan kerja terhadap kinerja karyawan di PT. Jasaraharja Cabang Pekanbaru (The effect of work experience, performance appraisal, and work relations on employee performance at PT. Jasaraharja Pekanbaru Branch). JOM Fekon. 4(1):912-925.

[8] Yendraliza. 2012. Karakteristik penampilan tubuh pejantan unggul kerbau lumpur (Bubalus bubalis) di Kabupaten Kampar (Characteristics of the body appearance of superior males of mud buffalo (Bubalus bubalis) in Kampar Regency). Agrinak.02(1):17-21.

[9] Sukri, A., H. Fitriyani., Supardi. 2016. Karakteristik morfologi kerbau lokal (Bubalus bubalis) Lombok Tengah Nusa Tenggara Barat (Morphological characteristics of local buffalo (Bubalus bubalis)
Central Lombok, West Nusa Tenggara). Universitas Nusantara PGRI. Kediri 